Original Research Article

\title{
Impact of educational intervention on the awareness of undergraduate medical students towards teratogenicity: an observational study
}

\author{
Rohini Gupta $^{1 *}$, Brij Mohan Gupta ${ }^{1}$, Apeksha Gupta ${ }^{2}$
}

${ }^{1}$ Department of Pharmacology and Therapeutics, GMC, Jammu, J\&K, India ${ }^{2}$ Department of Anaesthesia, ASCOMS, Jammu, J\&K, India

Received: 16 July 2018

Accepted: 11 August 2018

*Correspondence to:

Dr. Rohini Gupta,

Email: rohinigupta299@

ymail.com

Copyright: (C) the author(s), publisher and licensee Medip Academy. This is an openaccess article distributed under the terms of the Creative Commons Attribution NonCommercial License, which permits unrestricted noncommercial use, distribution, and reproduction in any medium, provided the original work is properly cited.

\begin{abstract}
Background: The term teratogenicity is defined as any morphological, behavioral or biochemical effect induced during embryonic life or fetal life detected at birth or later. the factors that lead to teratogenicity include both nongenetic and genetic factors. The objective of the present study was to assess the impact of educational interventions on the awareness of undergraduate medical students towards teratogenicity

Methods: The present study was a questionnaire-based comparative observational study carried out at Department of Pharmacology and Therapeutics, Government Medical College, Jammu (J\&K) for a period of three months from $1^{\text {st }}$ November 2017 to $31^{\text {st }}$ January 2018. The questionnaire was designed and validated by conducting pilot study on a sample of ten students. The questionnaire comprised of two main parts. The first part comprised of questions pertaining to the demographic profile of the students and second part consisted of questions assessing the students' knowledge and awareness towards teratogenicity. The scoring of the assessment of the performance of the students regarding knowledge of various aspects of teratogenicity was done before and after the educational intervention and was compared using paired t-test.

Results: A total of 134 second year MBBS undergraduate students participated in the study. Mean age of students was $19.32 \pm 0.82$ years. In the present study it was found that before the educational intervention about $98.5 \%$ of the students and after the intervention all the students were aware of the term teratogenicity. About $69.4 \%$ of students knew about all the causes that lead to teratogenicity but after the intervention about $76.1 \%$ of the students knew about it. Also, the percentage of students who knew about the name of two teratogenic drugs and two teratogenic defects associated with drugs were only $31.3 \%$ and $22.3 \%$ respectively. After the educational intervention it increased to $61.9 \%$ and $52.2 \%$ respectively.

Conclusions: In the present study, it was found that after the educational intervention, there was a significant improvement in the mean knowledge score of the students. This reflects the need of early exposure of students to this important issue of teratogenicity.
\end{abstract}

Keywords: Drugs, Pregnancy, Teratogenicity, Teratogenic factors, Undergraduate students

\section{INTRODUCTION}

The term teratogenicity is defined as any morphological, behavioral or biochemical effect induced during embryonic life or fetal life detected at birth or later. ${ }^{1,2}$ The term teratogen is originated from a Greek word 'teras' meaning a 'monster'. ${ }^{1}$ By definition, the factors that lead to teratogenicity include both non-genetic and genetic factors. ${ }^{3}$ Earlier, the teratogenic factors were generally believed to be inherited until the recognition of maternal rubella syndrome and subsequently, of thalidomide as a cause of birth defects. ${ }^{4-7}$ Thus, drugs were implicated as causative agents in teratogenesis only after the thalidomide disaster in 1961. This also led to the setting up of drug regulatory bodies in many countries. ${ }^{8}$ 
It was estimated that approximately $25 \%$ of human developmental defects are genetic in origin, $2-3 \%$ are due to drug exposure and about $65 \%$ are either unknown or from combination of genetic and environmental factors. ${ }^{9}$ Teratogenicity is a major cause of abortion, stillbirth and can result in long-term disability which can adversely influence not only the individuals, families and societies but also the healthcare system. ${ }^{10}$ Various mechanisms have been proposed in the causation of teratogenicity. These include folic acid deficiency, generation of epoxides or arena oxides which are oxidative intermetabolites of many drugs, interaction between environment and fetal genes, maternal diseases, drugs taken during pregnancy and activation of homeobox genes which are a group of regulatory genes that control the expression of other genes. Various teratogens like retinoic acid cause activation of these genes to cause abnormal gene expression. ${ }^{9}$

Drugs that lead to teratogenicity can affect the fetus at three stages:

i. Fertilization and implantation (Before Day 31): Teratogen produce an all or none effect. The conceptus either doesn't survive or survives without anomalies. In early conception, only few cells are there. So, any damage at that phase, is irrapairable and is lethal.

ii. D31-D71: is the critical period for organ formation. Effects of teratogen depends upon various factors like the amount of the drug reaching the fetus, gestational age at the time of exposure and duration of exposure.

iii. After D71: Other developmental and functional abnormalities can occur as development of other organs continues. ${ }^{9}$

The US-FDA has graded the documentation of risk for causing birth defects by various drugs into five categories i.e.; A (No risk), B (No evidence of risk in humans), C (Risk can't be ruled out), D (Benefit may outweigh the potential risk) and $\mathrm{X}$ (Contraindicated). ${ }^{11}$ In developing countries like India, where there is high birth rate; the annual birth defect prevalence is also high around 6-7\% which can have a significant impact on many health indicators of the country. ${ }^{12,13}$ It is quite evident from the previous studies that the clinicians are not very much equipped in taking a decision regarding prescribing of medications during pregnancy. ${ }^{14}$ Moreover, low adherence to medication is often found in pregnant women due to the perceived safety risks of the prescribed medications. Thus, medical practitioners have a key role to play in such situations in explaining the patient about the substantial benefits and small risk of medication not only to ensure better patient compliance and good illness control during pregnancy but also to decrease the excessive fear of drug teratogenicity among the patients. ${ }^{15}$

Thus, for the effective and safe prescribing during pregnancy, medical practitioners need to have a clear information regarding the principles of teratogenicity and be aware of which medications are safe to use during pregnancy. ${ }^{16}$ For this, it is very necessary to sensitize the undergraduate medical students who are the future healthcare professionals regarding the concept of teratogenicity. This will bridge the gap in their knowledge as well as it will help them to prescribe safely in future also. Therefore, keeping this in mind the present study was taken up to create awareness among the students about the concept of teratogenicity so that the incidence of preventable teratogenic defects can be decreased.

\section{METHODS}

The present study was a questionnaire-based comparative observational study carried out at Department of Pharmacology and Therapeutics, Government Medical College, Jammu (J\&K) for a period of three months from $1^{\text {st }}$ November 2017 to $31^{\text {st }}$ January 2018. The study involved second year MBBS students. The study was conducted after taking approval from the Institutional Ethical Committee. The questionnaire was designed and validated by conducting pilot study on a sample of ten students. Depending upon the response of the students in pilot study, certain modifications were done in the questionnaire and after taking written informed consent from the students, the questionnaires were distributed among the participants. The students who were not willing to participate and the students who took part in the pilot study were excluded from the study.

The questionnaire comprised of two main parts. The first part comprised of questions pertaining to the demographic profile of the students and second part consisted of questions assessing the students' knowledge and awareness towards teratogenicity. The assessment of their performance was based on the score $(0=$ wrong response and $1=$ correct response). The scoring of the assessment of the performance of the students regarding knowledge of various aspects of teratogenicity was done before and after the educational intervention. The educational intervention was done in the form of a lecture in the form of a power point presentation given on teratogenicity. In the lecture, the students were made aware about the various aspects of teratogenicity including its causative factors, most vulnerable period, mechanisms, outcome and categorization of drugs into various categories according to US-FDA risk categorization of causing birth defects by various drugs. The results were analysed both pre and post intervention and compared using paired t-test ( $p$ value $<0.05$ was taken as statistically significant).

\section{RESULTS}

A total of 134 second year MBBS undergraduate students participated in the study. Table 1 shows the demographic profile of the participants. Mean age of students was $19.32 \pm 0.82$ years. In the present study it was found that before the educational intervention about $98.5 \%$ of the students and after the intervention all the students were aware of the term teratogenicity. 
Table 1: Demographic profile of the participants.

\begin{tabular}{|llll|}
\hline Total & $\begin{array}{l}\text { Age (years) } \\
\text { Mean } \pm \text { SD }\end{array}$ & \multicolumn{2}{l|}{ Gender } \\
\hline 134 & $19.32 \pm 0.82$ & Male n (\%) & Female n (\%) \\
\cline { 3 - 4 } & & $69(51.5)$ & $65(48.5)$ \\
\hline
\end{tabular}

About $69.4 \%$ of students knew about all the causes that lead to teratogenicity but after the intervention about $76.1 \%$ of the students knew about it. Similarly, before the intervention $33.58 \%$ of students were able to name all the five US-FDA fetal risk categories and after the educational session the percentage of students who were able to name all the five risk categories increased to $61.9 \%$. Also, the percentage of students who knew about the name of two teratogenic drugs and two teratogenic defects associated with drugs were only $31.3 \%$ and $22.3 \%$ respectively. After the educational intervention it increased to $61.9 \%$ and $52.2 \%$ respectively. The details regarding the percentage response of students to various questions related to teratogenicity before the educational intervention and after that is summarized in Table 2 .

Table 2: Knowledge and awareness of students towards teratogenicity before and after educational intervention.

\begin{tabular}{|lll|}
\hline \multicolumn{1}{|c|}{ Questions } & $\begin{array}{l}\text { No. of correct responses at } \\
\text { pre-intervention = n (\%) }\end{array}$ & $\begin{array}{l}\text { No. of correct responses at } \\
\text { post-intervention= } \mathbf{n}(\%)\end{array}$ \\
\hline Are you aware of the term teratogenicity & $132(98.5)$ & $134(100)$ \\
\hline What are the causes of teratogenicity & $93(69.4)$ & $102(76.1)$ \\
\hline $\begin{array}{l}\text { Do you think that teratogenicity due to drugs can occur } \\
\text { during all the three trimesters? }\end{array}$ & $73(54.5)$ & $93(69.4)$ \\
\hline Can you name all the five US-FDA fetal risk categories? & $45(33.58)$ & $83(61.9)$ \\
\hline Can you name first drug teratogen? & $51(38.1)$ & $107(79.8)$ \\
\hline Can you name any two teratogenic drugs? & $42(31.3)$ & $70(52.2)$ \\
\hline $\begin{array}{l}\text { Can you name two teratogenic defects associated with } \\
\text { drugs? }\end{array}$ & $30(22.3)$ & $108(80.5)$ \\
\hline $\begin{array}{l}\text { What are the results/outcomes of teratogenicity? } \\
\text { Do you think that folic acid should be routinely } \\
\text { prescribed in pregnancy to prevent neural tube defects? }\end{array}$ & $97(72.3)$ & $87(64.9)$ \\
\hline $\begin{array}{l}\text { Do you think that an extra caution is required while } \\
\text { prescribing during pregnancy? }\end{array}$ & $110(82.1)$ & $116(86.5)$ \\
\hline $\begin{array}{l}\text { Do you think that a disease should not be untreated or } \\
\text { undertreated due to the fear of teratogenicity? }\end{array}$ & $115(85.8)$ & $121(90.2)$ \\
\hline $\begin{array}{l}\text { Do you think that there is a need of information on drugs } \\
\text { causing teratogenicity and their management strategies? }\end{array}$ & $126(94.1)$ & $131(97.7)$ \\
\hline
\end{tabular}

Table 3: Comparison of mean pre and post intervention knowledge score; intervention was in the form of lecture by PowerPoint presentation on teratogenicity.

\begin{tabular}{|llll|}
\hline Parameter & $\begin{array}{l}\text { Pre- } \\
\text { intervention }\end{array}$ & $\begin{array}{c}\text { Post- } \\
\text { intervention }\end{array}$ & p-value \\
\cline { 1 - 3 } $\begin{array}{l}\text { Knowledge } \\
\text { score }\end{array}$ & Mean \pm SD & Mean \pm SD & \\
\cline { 2 - 3 } & $7.27 \pm 1.36$ & $9.22 \pm 1.43$ & \\
\hline
\end{tabular}

Table 3 shows the comparison between the preintervention and post-intervention scores for the knowledge about teratogenicity among the students. It was observed that at post-intervention the mean knowledge score was $9.22 \pm 1.43$ which was higher than at preintervention. ( $\mathrm{p}$ value <0.05). The improvement in the knowledge score at post-intervention was statistically significant ( $\mathrm{p}$ value $<0.05$ )

\section{DISCUSSION}

Awareness regarding teratogenicity among undergraduate medical students is of utmost importance as teratogenic defects pose a great health challenge not merely to the patients but also to their families. Moreover, many of the teratogenic defects caused by the drugs are preventable in nature. ${ }^{17}$ So, it is the need of the hour to make students aware about this important issue. In the present study 134 Second year MBBS students participated in the study. In the present study at pre-intervention, majority of the students about $98.5 \%$ were aware about the term teratogenicity. Most of the students about $69.4 \%$ knew about all the causes that lead to teratogenicity but only $54.5 \%$ of the students were aware that teratogenicity due to drugs can occur during all the three trimesters. Mostly, it is observed that students have a misbelief that a drug is teratogenic only during the 1st trimester as organogenesis occurs during this period. They should be taught in detail 
about other developmental and biochemical abnormalities that can occur even when teratogenic drug exposure occurs in second and third trimesters. These results are consistent with the previous published studies. ${ }^{18,19}$

Also, very few percentages of students about $33.58 \%$ knew about all the five US-FDA risk categories. Also, only $33.2 \%$ and $22.3 \%$ of students were able to mention the names of two teratogenic drugs and teartogenic defects associated with drugs respectively.

Also, only $44.7 \%$ of students agreed that folic acid should be routinely prescribed in pregnancy to avoid neural tube defects. However, most of the students about $82.1 \%$ agreed that an extra caution is required while prescribing during pregnancy. Similarly, $85.8 \%$ of the students were aware of the fact that a disease should not be untreated or undertreated for the fear of teratogenicity.

Also, $94.1 \%$ of the students agreed that there is a greater need of information on drugs that lead to teratogenicity. This shows the willingness of students to acquire knowledge about the drugs that lead to teratogenicity. These results were consistent with the previous published studies. ${ }^{18,19}$ When the mean knowledge score of the students after the educational intervention was compared with the mean knowledge score at pre-intervention it was found that there was a significant improvement indicating the impact of educational session and scope for improvement with the early intervention among the students.

The limitations of present study were that of small sample size of students of same academic year of a single institution. In future, further studies can be done with large sample size with subjects representing different education level assessing both immediate as well as long term impact of the educational intervention.

\section{CONCLUSION}

In the present study, it was found that after the educational intervention, there was a significant improvement in the mean knowledge score of the students. This reflects the need of early exposure of students to this important issue of teratogenicity. Thus, multiple exposures relating to various aspects of teratogenicity need to be done among the undergraduate medical students at the earliest as they are the future health care professionals.

Funding: No funding sources Conflict of interest: None declared

Ethical approval: The study was approved by the Institutional Ethics Committee

\section{REFERENCES}

1. Bisht M, Dhasmana DC. Teratagenecity and Maternogenicity. Myths and Facts. RJPBCS 2014;5(1):452-69.
2. Sharma R. Birth defects in India: Hidden truth, need for urgent attention. Indian $\mathrm{J}$ Hum Genet. 2013;19(2):125-9.

3. Fraser FC. Foreward: What is teratology?. In: Hales B, Scialli A, Tassinari MS, editors. Teratology primer: Teratology society. 2010. p. viii-ix. Available at http://connection.teratology.org/p/cm/ld/ fid=6

4. Gregg NM. Congenital cataract following German measles in the mother. 1941. Aust N Z J Ophthalmol. 1991;19:267-76.

5. Webster WS. Teratogen update: Congenital rubella. Teratology. 1998;58:13-23.

6. McBride WB. Thalidomide and congenital abnormalities. Lancet. 1961;21358

7. Lenz W, Knapp K. Thalidomide embryopathy. Arch Environ Health. 1962; 5:100-105.

8. Rang HP, Dale MM, Ritter JM, Fowler RJ. The Harmful effects of drugs. In: Rang and Dale's pharmacology, 6th edition. Edinburgh, UK: Churchill Livingstone 2007; Chapter 53:pp.757-758.

9. Dutta DC. Pharmacotherapeutics in Obstetrics. In: Konar $\mathrm{H}$ (editor), Textbook of obstetrics including perinatology and contraception, $6^{\text {th }}$ edition. New Central Book Agency (P) LTD, 2006;511.

10. World Health Organization. Fact sheet: Congenital anomalies, 2016. Available at http://www.who.int/mediacentre/factsheets/fs370/en/. Accessed on $11^{\text {th }}$ December, 2017.

11. Tripathi KD. Adverse drug effects. Section I: General Pharmacological Principles. In : Essentials of Medical Pharmacology, $7^{\text {th }}$ edition. Jaypee Brothers Medical Publishers (P) Ltd. 2013;89-90.

12. National Health Portal. Congenital anomalies (birth defects), 2016. Available at https://www.nhp.gov.in/disease/gynaecologyandobstetrics/congenital-anomalies-birth-defects. Accessed on $11^{\text {th }}$ December 2017.

13. Kar A. Birth Defects in India: Magnitude, Public Health Impact and Prevention. JKIMSU. 2014;3(2):716.

14. Banhidy F, Lowry RB, Czeizel AE. Risk and benefit of drug use during pregnancy. Int $\mathrm{J}$ Med Sci. 2005;2:100-6.

15. Yawn B, Knudtson M. Treating asthma and comorbid allergic rhinitis in pregnancy. J Am Board Fam Med. 2007;20:289-98.

16. Yankowitz J, Niebyl JR. Drug Therapy in Pregnancy. $3^{\text {rd }}$ ed. USA: Lippincott Williams \& Wilkins; 2001.

17. Centers for Disease Control and Prevention. Understanding the Causes of Major Birth Defects: Steps to Prevention, 2015. Available at https://www.cdc.gov/cdcgrandrounds/pdf/archives/20 15/january2015.pdf. Accessed on $18^{\text {th }}$ December 2017.

18. Kumari P, Krishnaiah V, Kumaraswamy G, Tamboli TJ. Impact of educational session on knowledge and attitude towards teratogenicity among undergraduate medical students: a comparative study. Int J Basic Clin Pharmacol. 2017;6:2642-5. 
19. Banu G, Khan AAK. A questionnaire based survey on knowledge, attitude and practices of medical practitioners regarding the prescribing of medications during pregnancy. Int $\mathrm{J}$ Reprod Contracept Obstet Gynecol. 2016;5:984-8.
Cite this article as: Gupta R, Gupta BM, Gupta A. Impact of educational intervention on the awareness of undergraduate medical students towards teratogenicity: an observational study. Int J Basic Clin Pharmacol 2018;7:1842-6. 